\title{
PENGARUH PARTISIPASI MANAJER TERHADAP EFEKTIVITAS SISTEM INFORMASI AKUNTANSI
}

\author{
Ikromi Abd Ghani HSB ${ }^{1)}$, Dovi Septiari ${ }^{2}$ \\ Jurusan Manajemen Bisnis, Politeknik Negeri Batam \\ Jl. Ahmad Yani, Batam Centre, Batam 29461, Indonesia \\ 1)E-mail: ghani.romy@gmail.com \\ 2)E-mail: dovi@polibatam.ac.id
}

\begin{abstract}
Abstrak
Perkembangan dalam lingkungan bisnis di era globalisasi ini memicu terjadinya persaingan bisnis yang semakin ketat. Setiap perusahaan yang didirikan memiliki strategi tersendiri dalam mengelola berbagai informasi, sumber daya manusia, alokasi dana dan lain-lain. Sistem informasi akuntansi itu sendiri merupakan sumber daya yang sangat bernilai bagi suatu organisasi demi kelancaran pengelolaan keuangan perusahaan serta dalam pembuatan decision making baik itu untuk jangka panjang maupun jangka pendek, namun ada beberapa aspek yang menjadi faktor efektivitas sistem informasi akuntansi itu sendiri yakni partisipasi manajer. Penelitian ini bertujuan untuk membuktikan bahwa partisipasi manajer dan keterlibatan manajer memberikan pengaruh positif dalam efektifitas sistem informasi akuntansi (SIA) di perusahaan manufaktur khususnya pada Kawasan Industri Batamindo Mukakuning kota Batam. Metode penelitian yang digunakan adalah analisis regresi dengan membuktikan partisipasi manajer (independent variable) dan keterlibatan manajer (independent variable) memberikan pengaruh kepada efektivitas sistem informasi (dependent variable). Hasil dari penelitian ini menunjukkan bahwa variabel partisipasi manajer dan keterlibatan manajer berpengaruh signifikan terhadap efektifitas sistem informasi.
\end{abstract}

Kata Kunci: Partisipasi Manajer, Keterlibatan Manajer, Efektivitas Sistem Informasi Akuntansi

\begin{abstract}
The development of the business environment in globalization era has been triggered an increasingly tight business competition. Every companies who have an established its own strategies to manage a variety of information, human resources, allocation of funds and others. Accounting information system is a great resources that very valuable to an organization for the smoothness management of the company's financial and decision making wheter it is to long term and short term, however there are several aspect that can be a factors the effectiveness of the accounting information system, that is manager's participation. The research is aimed to proves that manager's participation and manager's involvement had a positive influence on the effectiveness of accounting information system (AIS) at manufacturing company, especially in the industrial zone Batamindo Mukakuning Batam City. The research method is using regression analysis to proves are the manager's participation (independent variable) and manager's involvement (independent variable) gives effect to the effectiveness of information system (dependent variable) or not. The result of this research is shows that variable of manager's participation and manager's involvement has a significant influence to the effectiveness of information system. The method is using purposive sampling is done by taking a sampling of the population according to certain criteria.
\end{abstract}

Keywords: Manager's participation, manager's involvement, effectiveness of accounting information system 


\section{Pendahuluan}

\subsection{Latar Belakang}

Perkembangan dalam lingkungan bisnis di era globalisasi ini memicu terjadinya persaingan bisnis yang semakin ketat sehingga membuat para pengusaha terus bekerja keras untuk menjadikan perusahaannya lebih unggul dibanding dengan kompetitornya. Setiap perusahaan yang didirikan memerlukan sistem yang terstruktur untuk menghasilkan informasi yang dibutuhkan sehingga informasi tersebut dapat bermanfaat bagi kemajuan perusaahan. Adapun upaya untuk mendapatkan dan menghasilkan informasi yang memadai dan akurat dalam kerangka sistem disebut dengan sistem informasi (SI). Salah satu penerapan teknologi informasi yang sangat berperan penting di dalam kegiatan perusahaan yaitu penerapan sistem informasi akuntansi. Sistem informasi akuntansi ini juga digunakan oleh perusahaan sektor industri yang mengolah bahan mentah, bahan baku, ataupun barang setengah jadi menjadi barang yang mempunyai nilai lebih tinggi dari penggunaannya. Penelitian sebelumnya telah dilakukan di Malaysia oleh Ismail yang menguji efektivitas sistem informasi dan pengaruhnya bagi perusahaan dengan model pengujian yang diusulkan yakni, kecanggihan sistem informasi, partisipasi manajer, pengetahuan manajer dan keefektivitasan dalam pelaksanaan sistem informasi. Hasil penelitian tersebut terdapat variabel yang tidak signifikan yakni; kecanggihan sistem informasi akuntansi, partisipasi manajer dan pengetahuan manajer tentang sistem informasi akuntansi tidak berhasil didukung oleh data. Ketidakberhasilan peneliti sebelumnya membuat penulis tertarik untuk melakukan penelitian dengan membentuk partisipasi manajer tersebut menjadi dua bagian yakni: a) partisipasi manajer, b) keterlibatan manajer.

\subsection{Perumusan Masalah}

Berdasarkan latar belakang di atas, maka rumusan masalah dalam penelitian ini adalah apakah partisipasi manajer dan keterlibatan manajer berpengaruh terhadap efektivitas sistem informasi.

\subsection{Tujuan Penelitian}

Berdasarkan perumusan masalah di atas dapat disusun tujuan dalam penelitian ini yaitu untuk menguji hubungan partisipasi manajer dan keterlibatan manajer terhadap efeltvitas sistem informasi akuntansi pada perusahaan.

\section{Landasan Teori}

\subsection{Sistem Informasi Akuntansi}

Sistem informasi berisi informasi tentang orangorang, tempat dan hal-hal penting di dalam organisasi atau lingkungan sekelilingnya ${ }^{[1]}$. Sistem informasi akuntansi adalah sebuah sistem yang memproses data dan transaksi guna menghasilkan informasi yang bermanfaat untuk merencanakan, mengendalikan dan mengoperasikan bisnis ${ }^{[2]}$. Sistem informasi akuntansi merupakan kumpulan sumber daya yang dirancang untuk mengubah data keuangan dan data lainnya ke dalam informasi ${ }^{[3]}$

\subsection{Faktor-Faktor yang Mempengaruhi} Efektivitas Sistem Informasi Akuntansi

Efektivitas adalah kesuksesan harapan atas hasil yang diperoleh dari pekerjaan yang telah dilakukan ${ }^{[4]}$. Efektivitas sebagai suatu keberhasilan kualitas, kuantitas dan waktu yang digunakan dan hasil kerja yang telah dicapai ${ }^{[5]}$. Faktor yang mempengaruhi efektivitas sistem informasi akuntansi adalah keterlibatan pemakai yang semakin sering, semakin tinggi kemampuan teknik personal sistem informasi, semakin besar dukungan manajer yang diberkan kepada bawahannya, program pelatihan dan pendidikan pemakaian, keberadaan dewan $\operatorname{pengarah}^{[6]}$.

\subsection{Partisipasi Manajer dalam Efektivitas Sistem Informasi}

Partisipasi Manajer dikonseptualisasikan sebagai keterlibatan dan partisipasi eksekutif atau manajemen di bidang teknologi informasi/ sistem informasi ${ }^{[7]}$. Partisipasi manajemen dalam memberikan dukungan merupakan suatu panduan mengenai komitmen dan dukungan atas segala sumber daya yang diperlukan oleh perusahaan ${ }^{[8]}$. Kecanggihan teknologi informasi 
dan partisipasi manajemen memiliki pengaruh yang signifikan tehadap efektivitas sistem informasi akuntansi $^{[9]}$. Penelitian sebelumnya juga menunjukkan bahwa pengaruh dukungan manajemen terhadap sistem informasi akuntansi sangat kuat ${ }^{[10]}$.

\subsection{Keterlibatan Manajer}

Keterlibatan manajer menggambarkan persepsi manajer tentang identitas atau hal-hal penting di dalan kelompoknya $^{[11]}$. Sementara keterlibatan terdiri dari beberapa inisiatif menggunakan konsep Total Quality Management $^{[12]}$.

\section{Hasil Dan Pembahasan}

\subsection{Karakteristik Responden Berdasarkan Status Karyawan}

Berdasarkan status karyawan dan manajemen pada perusahaan dibagi menjadi dua yaitu karyawan tetap dan karyawan tidak tetap. Hasil kuesioner yang disebarkan ditemukan bahwa karyawan tetap lebih dominan dibandingkan dengan karyawan tidak tetap. Hasil pengolahan data dapat dilihat bahwa karyawan tetap sebanyak 83 orang dengan tingkat persentase $83 \%$ dan karyawan berstatus tidak tetap sebanyak 17 orang dengan tingkat persentase $17 \%$.

\subsection{Karakteristik Karyawan Berdasarkan Jenis}

\section{Kelamin}

Berdasarkan jenis kelamin pada perusahaan dibagi menjadi dua yaitu laki-laki dan perempuan. Hasil kuesioner yang disebarkan ditemukan bahwa responden berjenis kelamin laki-laki sebanyak 65 orang dengan tingkat persentase $65 \%$ dan responden berjenis kelamin perempuan sebanyak 35 orang dengan tingkat persentase $35 \%$.

\subsection{Hasil Pengujian Validitas}

Hasil uji validitas menunjukkan bahwa semua variabel independen dan dependen dalam hal ini partisipasi manajer (independen), keterlibatan manajer (independen) dan efektivitas sistem informasi akuntansi (dependen) dinyatakan valid.

\subsection{Hasil Pengujian Reliabilitas}

Berdasarkan hasil pengujian reliabilitas dapat diketahui bahwa nilai cronbcah alpha dari seluruh variabel yang diajukan nilainya sudah di atas 0,60 maka dapat disimpulkan bahwa seluruh variabel dalam penelitian ini lolos dalam uji reliabilitas.

\subsection{Hasil Pengujian Multikolinearitas}

Hasil perhitungan nilai tolerance pada pengujian multikolinearitas menunjukkan bahwa variabel independen memiliki nilai tolerance $>0,10$ yang berarti tidak terjadi multikolinearitas. Hasil perhitungan nilai variance inflation factor juga menunjukkan hal yang sama tidak ada satu variabel independen yang memiliki nilai VIF lebih dari 10, sehingga dapat disimpulkan tidak terdapat multikolinearitas antar variabel independen dalam model regresi.

\subsection{Hasil Pengujian Heteroskedastisitas}

Berdasarkan pengujian yang telah dilakukan telah menunjukkan bahwa variabel bebas signifikan secara statistik mempengaruhi variabel dependen, dengan signifikansi lebih besar dari 0,05 sehingga dapat disimpulkan model regresi tidak mengandung heteroskedastisitas.

\subsection{Hasil Pengujian Normalitas}

Berdasarkan pengujian yang telah dilakukan menunjukkan bahwa nilai signifikansi sebesar 0,169 lebih besar dari 0,05, dengan demikian dapat dinyatakan bahwa distribusi data dari masing-masing variabel berdistribusi normal.

\subsection{Hasil Uji Regresi Linear Sederhana}

Berdasarkan hasil uji regresi dapat diketahui nilai thitung sebesar 19,480 dengan nilai signifikansi $0,000<0,05$, maka H1 diterima yang berarti ada pengaruh yang signifikan antara variabel keterlibatan manajer (X2) terhadap variabel efektivitas sistem informasi akuntansi (Y). apabila keterlibatan manajer ditingkatkan akan meningkatkan efektivitas sistem informasi akuntansi sebesar 1,044 yang berarti bahwa keterlibatan manajer berkontribusi positif terhadap efektivitas sistem informasi akuntansi pada perusahaan. 


\subsection{Partisipasi Manajer Terhadap Efektivitas}

\section{Sistem Informasi Akuntansi}

Hasil dari penelitian sebelumnya menunjukkan bahwa partisipasi manajer tidak memberikan kontribusi positif terhadap efektivitas sistem informasi akuntansi karena manajer perusahaan kecil harus langsung terlibat dalam sistem informasi dari pada sekedar berpartisipasi dalam efektivitas sistem informasi, hal tersebut terjadi dikarenakan sampel yang diambil untuk penelitian adalah perusahaan-perusahaan kecil (UKM) ${ }^{[13]}$. Teori partisipasi manajer dan keterlibatan manajer yang menyatakan bahwa partisipasi manajer dikonseptualisasikan sebagai keterlibatan dan partisipasi eksekutif atau manajemen di bidang teknologi informasi (TI)/ sistem informasi ${ }^{[8]}$. Hipotesis ini terdukung oleh data dengan tingkat koefisien 0,792 yang dapat diartikan bahwa apabila partisipasi manajer ditingkatkan akan meningkatkan efektivitas sistem informasi akuntansi sebesar 0,792 yang berarti bahwa partisipasi manajer berkontribusi positif terhadap efektivitas sistem informasi akuntansi pada perusahaan.

\subsection{Keterlibatan Manajer Terhadap Efektivitas}

\section{Sistem Infromasi Akuntansi}

Hasil penelitian sebelumnya menunjukkan bahwa ada beberapa faktor yang mempengaruhi penggunaan sistem informasi yakni partisipasi manajer (executive participation) dan keterlibatan manajer (executive involvement), dari penelitian tersebut menjelaskan bahwa keterlibatan manajer lebih penting atau berpengaruh terhadap sistem informasi dibandingkan partisipasi manajer, sekalipun partisipasi manajer tetap memberikan dampak positif terhadap efektivitas sistem informasi. Hipotesis kedua ini terdukung oleh data dengan tingkat koefisien 0,358 yang dapat diartikan bahwa apabila keterlibatan manajer ditingkatkan akan meningkatkan efektivitas sistem informasi akuntansi sebesar 0,358 yang berarti bahwa keterlibatan manajer berkontribusi positif terhadap efektivitas sistem informasi akuntansi pada perusahaan $^{[14]}$.

Hasil penelitian ini menunjukkan keterlibatan manajer terhadap sistem informasi partisipasi manajer itu terdiri atas dua bentuk yakni, a) Executive participation dan b) Executive Involvement. Dalam penelitian ini sistem informasi tersebut dipersempit menjadi sistem informasi akuntansi.

Pengujian hipotesis menggunakan statistik regresi berganda, pengujian dilakukan untuk melihat pengaruh antar variabel partisipasi manajer (X1) dan keterlibatan manajer (X2) terhadap efektivitas sistem informasi atau SIA (Y) 61 perusahaan yang terdapat di kawasan Batamindo Mukakuning kota Batam.

Berdasarkan hasil analisis diketahui nilai signifikansi uji untuk variabel partisipasi manajer sebesar $0,000<5 \%$ yang menunjukkan bahwa partisipasi manajer berpengaruh atas efektivitas sistem informasi akuntansi (AIS) dan nilai signifikansi uji untuk variabel katerlibatan manajer sebesar $0,000<5 \%$ yang menunjukkan bahwa keterlibatan manajer berpengaruh terhadap efektivitas sistem informasi akuntansi (AIS).

Kondisi ini sesuai dengan yang peneliti harapkan karena sudah seharusnya partisipasi manajer dan keterlibatan manajer memberikan dampak positif terhadap tingkat efektivitas penggunaan sistem informasi akuntansi pada perusahaan.

\section{Kesimpulan}

\subsection{Kesimpulan}

Penelitian ini berisikan suatu model untuk menguji pengaruh partisipasi manajer dan keterlibatan manajer terhadap efektivitas sistem informasi akuntansi (AISE). Berdasarkan hasil pengujian regresi dengan SPSS, dapat disimpulkan bahwa:

a. Partisipasi manajer berpengaruh terhadap efektivitas sistem informasi akuntansi (AISE).

b. Keterlibatan Manajer berpengaruh terhadap efektivitas sistem informasi akuntansi (AISE).

\subsection{Keterbatasan}

Terdapat beberapa keterbatasan yang kemungkinan dapat berpengaruh pada hasil penelitian. Keterbatasan tersebut adalah sebagai berikut:

a. Penelitian ini hanya dilakukan pada perusahaan manufaktur yang terdaftar di Batamindo Investment 
Cakrawala bukan pada seluruh perusahaan yang ada di kota Batam.

b. Variabel yang dipergunakan hanya tiga variabel yakni partisipasi manajer, keterlibatan manajer dan efektivitas sistem informasi (AIS), sedangkan faktorfaktor lain seperti kecanggihan AIS, pengetahuan manajer terhadap AIS (manager AIS knowledge), efektivitas konsultan (consultant effectiveness), efektivitas lembaga pemerintahan ( government agency effectiveness) dan kecanggihan sistem informasi akuntansi (AIS Shopistication).

\subsection{Implikasi}

Penelitian ini menguji pengaruh partisipasi manajer dan keterlibatan manajer terhadap efektivitas sistem informasi akuntansi. Dari penelitian ini, dapat disimpulkan bahwa partisipasi manajer dan keterlibatan manajer dapat memberikan kontribusi positif terhadap efektivitas sistem informasi akuntansi dan hal tersebut bisa menjadi tolak ukur bagi perusahaan dalam pengambilan keputusan. Hasil penelitian ini dapat digunakan sebagai:

a. Sebagai tambahan pengetahuan dan wawasan bagi penulis berkaitan dengan pengaruh partisipasi manajer terhadap efektivitas sistem informasi akuntansi.

b. Menambah kazanah ilmu pengetahuan dan menjadi tambahan refrensi mencakup pengaruh partisipasi manajer terhadap efektivitas sistem informasi akuntansi.

c. Memberikan informasi dan kontribusi bagi para manajer perusahaan bahwa partisipasi manajer memberikan dampak positif terhadap efektivitas sistem informasi akuntansi dan juga dapat membantu dalam pengambilan keputusan.

\subsection{Saran}

Adapun saran yang dapat disimpulkan dari penelitian yang telah dilakukan adalah sebagai berikut:

a. Bagi pihak perusahaan, dengan adanya pengaruh variabel seperti pada kesimpulan diatas, maka dapat ditingkatkan lagi penggunaan sistem informasi akuntansi mengingat sistem informasi akuntansi memiliki peran yang sangat penting dalam pengambilan keputusan oleh para pihak manajemen atas.

b. Bagi peneliti berikutnya dapat mengembangkan penelitian ini dengan menambah variabel penelitian, baik dalam variabel bebas ataupun dalam variabel terikat seperti; Kecanggihan AIS, pengetahuan manajer terhadap AIS (manager AIS knowledge), efektivitas konsultan (consultant effectiveness), efektivitas lembaga pemerintahan (government agency effectiveness) dan kecanggihan sistem informasi akuntansi (AIS Shopistication).

\section{Daftar Referensi}

Kenneth \& Jane, "Sistem Informasi Manajemen", Jakarta: Salemba Empat, 10 ed, 2007.

Krismiaji, "Sistem Informasi Akuntansi”, Yogyakarta, Indonesia: UPP AMP YKPN, (Kedua ed.), 2005.

Bodnar, G. H., \& Hopwood, W.S., "Sistem Informasi Akuntansi”(D. Prabantini, Ed., J.A. Saputra, \& L. Setiawati, Trans.), Yogyakarta, Indonesia: ANDI, Sembilan Ed, 2006.

Wahyu, K, “Analisis Pengaruh Efektivitas Teknologi Informasi Akuntansi Terhadap Kinerja Individual", Jurnal Akuntansi Fakultas Ekonomi Universitas Gunadarma, 2012.

Halomoan, O, "Pengaruh Penerapan Sistem Informasi Akuntansi Terhadap Sistem Pengendalian Internal”, Jurnal Ilmiah Akuntansi, vol. 1, no.2, 4, 2002.

Jen Fung, T, "Faktor-Faktor yang Mempengaruhi Kinerja Sistem Informasi Akuntansi”, Jurnal Bisnis dan Akuntansi, vol 4, no. 2, 135-154, 2002.

Igbaria, M., Zinatelli, N., Cragg, P., \& Cavaye, A, "Personal Computing Acceptance Factors in Small Firms: Structural Euation Model. MIS Quarterly 5, 1997.

Mooney, A., Mahoney, M., \& Wixom, B, “Achieving TopManagement Support in Strategi Technology Initiative", Howe School Alliance For Technology Management, vol 12, (2), 3, 2008.

Dwitriyani, M. C, "Pengaruh Kecanggihan IT dan Partisipasi Manajemen terhadap Efektivitas 
Sistem Informasi Akuntansi BPR di Kabupaten

Bandung”, Skripsi Fakultas Ekonomi Universitas

Udayana Denpasar, 4, 2012

Susilastri, Tanjung, A. R., \& Pebrina, S., "Faktor-

Faktor Yang Mempengaruhi Kinerja Sistem

Informasi Akuntansi pada Bank Umum

Pemerintah Di Kota Pekanbaru”, Jurnal Ekonomi,

121-132, 2010.

Joel, L. N., "The Relationship And Effect Of Employee

Involvement, Employee Empowerment, And

Employee Satisfaction By Job-Type In Large

Manufacturing Environment" A Disertation,

Capella University, 2004.

Lau \& Anthony, M., "Behavioral Effect of Non

Financial Performance Measure: The Role of

Procedural Fairness", Behavioral Research In

Accounting 20, 2008.

Ismail, N. A., "Factors Influencing AIS Effectiveness

Among Manufacturing SMEs", College of

Business, vol 38, 7, 2009.

Jarvenpaa, S. L., \& Ives, B., "Executive Involvement and Participation in the Management of information Technology”. MIS Quartely 15, 205 -

227, 1991. 